\title{
EL ESTATUTO DE "REFUGIADO" EN LA CONVENCIÓN DE GINEBRA DE 1951
}

\author{
SERGIO PÉREZ BARAHONA \\ Becario F.P.U. Área de Filosofía del Derecho \\ Universidad de La Rioja
}

\begin{abstract}
SUMARIO
I. Introducción. II. Cuestiones preliminares: aspectos terminológicos. III. La Convención de Ginebra de 1951 y el Protocolo de Nueva York de 1967 sobre el estatuto de los refugiados. IV. La admisión del refugiado: la obligación de non-refoulement. Especial referencia al art. 33 de la Convención de Ginebra de 1951. V. El concepto de refugiado según la Convención de Ginebra de 1951: el refugiado estatutario. V.1. El concepto de refugiado. Las cláusulas de inclusión. V.2. Cláusulas de exclusión. V.3. Cláusulas de cesación. VI. El status individual. VI.1. La posición del solicitante de refugio y el procedimiento de tramitación de una solicitud de reconocimiento del status de refugiado. VI.2. El status de refugiado. VII. Refugiados de hecho Vs Refugiados estatutarios. VIII. Conclusiones.
\end{abstract}

\section{RESUMEN}

El presente trabajo aborda el concepto de refugiado conforme se encuentra definido en el Convenio de Ginebra de 1951 y el Protocolo de Nueva York de 1967 sobre el estatuto de los refugiados. En el actual escenario global, y tras la proliferación de conflictos bélicos con ocasión del desmoronamiento de los regímenes comunistas, cobra de nuevo actualidad la problemática suscitada en torno a las víctimas de dichos conflictos. Considero oportuno una revisión del concepto de refugiado, como categoría de Derecho internacional, por lo que el presente trabajo recoge las críticas dirigidas al "estrecho" concepto de refugiado contemplado en la Carta ginebrina, y se apuesta por un concepto más amplio que albergue las situaciones que se producen en la actualidad. 


\section{INTRODUCCIÓN}

La protección internacional que reciben los refugiados ha cobrado en los últimos cincuenta años -desde la creación del Alto Comisionado de Naciones Unidas para los Refugiados en 1950 y la aprobación del Convenio de Ginebra de 1951- una creciente importancia. Por ello, hoy en día, podemos hablar de un Derecho internacional de los refugiados.

Las circunstancias acaecidas en los últimos años, la guerra en la antigua Yugoslavia o la más reciente guerra de Afganistán, nos hacen reflexionar sobre la protección internacional que se debe otorgar a los refugiados. De hecho, hoy en día, el concepto de refugiado contenido en la Convención de Ginebra de 1951 y en su Protocolo de 1967, está en entredicho, pues se trata de instrumentos adoptados para solucionar la situación de los refugiados ocasionados por la Segunda Guerra Mundial. Sin embargo, lo que se creía que era un problema temporal y geográficamente localizado, se ha convertido en un problema a escala mundial y de gran relevancia en el comienzo del siglo XXI.

Este trabajo tiene como objetivo definir el concepto de refugiado y su estatuto legal conforme a la Convención de Ginebra de 1951. Una ver fijados los límites concretos del estatuto de refugiado (condiciones para ser reconocido como tal conforme a la Convención de Ginebra; y derechos y obligaciones que conlleva dicho estatuto legal) abordaré el estudio de aquellas figuras de refugiado que no gozan de protección internacional conforme al Convenio de Ginebra.

Ahora bien, considero que es de vital importancia también el hecho de fijar el alcance concreto del concepto de refugiado definido en la Convención de Ginebra para el Derecho comunitario. Efectivamente, el Tratado de Amsterdam, en su Título IV (Arts. 61-69 TCE), prevé la creación del llamado Espacio de Libertad, Seguridad y Justicia en la Unión Europea. Dicho Espacio de Libertad, Seguridad y Justicia común, aunque con límites temporales (prevé un plazo de cinco años desde la entrada en vigor del Tratado de Amsterdam en el cual se deberán adoptar las medidas necesarias -hasta el 1 de mayo de 2004-) y espaciales (regímenes especiales para Reino Unido e Irlanda) afecta a la libertad de circulación en el ámbito comunitario. Sin embargo, no se puede concebir un espacio común sin fronteras interiores, sin tomar las medidas de acompañamiento necesarias que permitan efectivamente la libertad de circulación para todas las personas (comunitarios y no comunitarios) dentro del ámbito comunitario.

Estas medidas de acompañamiento inciden directamente en materias como la inmigración y el asilo, que dejan de ser una competencia exclusiva de los Estados, para ser una competencia compartida con la Unión Europea.

Pues bien, dicha competencia comunitaria en materia de asilo tiene un carácter limitado. Tal y como señala MARTÍN Y PÉREZ DE NANCLARES, el Consejo no tiene competencia para dictar una normativa armonizadora completa en materia de asilo ${ }^{1}$. Las normas armonizadoras comunitarias a dictar en materia de asilo serán de carácter procesal, y no material. No se va a poder dictar una normativa comunitaria sobre el

\footnotetext{
${ }^{1}$ MARTÍN Y PÉREZ DE NANCLARES, J.: La Inmigración y el Asilo en la Unión Europea, Colex, Madrid, 2002. pp.210-212
} 
estatuto de refugiado, sino que la competencia comunitaria sólo alcanza a dictar normas "mínimas" para la concesión de dicho estatuto o respecto a los procedimientos a tener en cuenta por los Estados a la hora de conceder o retirar dicho estatuto de refugiado.

Por ello, el Art. 63.1 TCE establece como competencia comunitaria la adopción de medidas de acompañamiento (normas mínimas) en materia de asilo, siempre con arreglo a los tratados internacionales pertinentes en la materia, señalando expresamente la Convención de Ginebra de 1951 y su Protocolo de 1967 sobre el estatuto de refugiados.

En este sentido, se produce una especie de remisión del Derecho comunitario al Derecho internacional público, una especie de límite a la intervención comunitaria en materia de asilo. La intervención comunitaria en materia de asilo debe respetar el marco iusinternacional universal existente en dicha materia (Convenio de 1951 y Protocolo de 1967) y el concepto de refugiado que de él se deriva. Por eso, también para el Derecho comunitario es relevante el estudio del alcance del concepto de refugiado que se recoge en el Convenio de Ginebra. Dicho concepto es el que a continuación me propongo analizar.

\section{CUESTIONES PRELIMINARES: ASPECTOS TERMINOLÓGICOS}

El estudioso del fenómeno del asilo y refugio, y de su consiguiente regulación jurídica, se enfrenta a un primer problema: la delimitación conceptual de los términos asilo y refugio.

En principio, tal y como señala DÍEZ DE VELASCO, por asilo "se entiende la protección que un Estado ofrece a personas que no son nacionales suyos y cuya vida o libertad están en peligro por actos, amenazas y persecuciones de las Autoridades de otro Estado o incluso por personas o multitudes que hayan escapado al control de dichas Autoridades".2

Se trata de un concepto amplio, en contraposición del concepto de refugiado, de alcance más limitado. Así, del VALLE GÁLVEZ señala que "el asilo sería un conjunto de garantías provisionales de entrada y estancia, que se concede a un extranjero por el Estado de acogida, discrecionalmente y con carácter previo al reconocimiento jurídicoadministrativo del estatuto de refugiado de la Convención de Ginebra". Y, además añade, que "el asilo sería también la posterior protección territorial del Estado, consecuencia de la determinación de la condición de refugiado, que se concede según las normas internas estatales articuladas sobre la base de la Convención de Ginebra".3

En este sentido el asilo se configura como una potestad del Estado basado en el principio de soberanía nacional. No existe un derecho de asilo a nivel internacional por parte de los individuos, sino que el asilo se configura como una facultad regaliana del Estado, quien soberanamente tendrá la facultad de conceder asilo o no a un individuo.

${ }^{2}$ En DÍEZ DE VELASCO, M.: Instituciones de Derecho Internacional Público, Ed.Tecnos, Madrid, 1994. p.629.

${ }^{3}$ En LÓPEZ ESCUDERO, M./MARTÍN Y PÉREZ DE NANCLARES, J. (coords.), Derecho Comunitario Material, Ed.McGrawHill, Madrid, 2000. p.57. 
La doctrina iusinternacionalista, a su vez, distingue dos manifestaciones principales del derecho de asilo: el asilo territorial y el asilo diplomático.

El asilo territorial es la protección que proporciona un Estado (Estado de acogida) a una persona nacional de un Estado distinto que sufre persecución política o ideológica, acogiéndole en su propio territorio. El elemento clave, por tanto, es que el asilo territorial se lleva a cabo en el territorio del Estado protector.

Por otro lado, el asilo diplomático consiste en la protección que dispensa un Estado a una persona perseguida política o ideológicamente, quien, para huir de dicha persecución se refugia en una misión diplomática acreditada de otro Estado. El Estado donde se encuentra dicha misión diplomática debe abstenerse de entrar en los locales de la misma, y además, debe garantizar la salida del asiliado al extranjero.

La figura del asilo diplomático es una figura de Derecho internacional iberoamericano, no de Derecho internacional general, ya que únicamente es una costumbre internacional de ámbito regional. ${ }^{4}$

El asilo territorial no ha tenido, sin embargo, una regulación convencional a nivel internacional. Por contra, el estatuto de refugiado viene regulado en el Convenio de Ginebra de 28 de julio de 1951 sobre el Estatuto de los Refugiados ${ }^{5}$ y en el Protocolo de Nueva York de 31 de enero de $1967^{6}$; además de contar con el Alto Comisionado de las Naciones Unidas para los Refugiados (ACNUR). ${ }^{7}$

De esta forma, el "refugio" se ha configurado como una clase particular de asilo. Dentro de la categoría del refugio, podemos distinguir lo que denominaríamos refugio estatutario y refugio de hecho. ${ }^{8}$ El refugio estatutario sería aquél que se contempla en el Convenio de Ginebra de 1951 como concepto de refugiado. Por otro lado, fuera del "reducido" concepto de refugiado según el Convenio de Ginebra de 1951 se producirían figuras no contempladas en el mismo, que constituyen lo que se conoce como refugiado de hecho.

Según el Convenio de 1951, como más adelante analizaré, el refugiado es una persona que sufre o tiene fundados temores de sufrir persecución individualizada por motivos de raza, religión, nacionalidad, pertenencia a un grupo social o por opiniones políticas, encontrándose fuera de su país y sin querer regresar a él. Se trata de estatuto legal de refugiado contemplado por el Convenio de 1951.

\footnotetext{
${ }^{4}$ Sobre el derecho de asilo, asilo territorial y asilo diplomático, véase PASTOR RIDRUEJO, J. A.: Curso de Derecho Internacional Público y Organizaciones Internacionales.Ed.Tecnos, Madrid, 1994. pp. $255-258$.

Convenio de 28 de julio sobre el Estatuto de los Refugiados, Ginebra, 28 de julio de 1951; publicado en TORRES UGENA, N.: Textos normativos de Derecho Internacional Público. Ed.Civitas, Madrid, 2000. pp.582-595. La Convención entra en vigor con carácter general el 22 de abril de 1954, para España el 14 de agosto de 1978 (BOE núm. 252, de 21 de octubre de 1978; corrección de errores en BOE núm. 272, de 14 de noviembre)

${ }^{6}$ Protocolo sobre el Estatuto de los Refugiados, Nueva York, 31 de enero de 1967; publicado en TORRES UGENA, N.: op. cit. (“Textos normativos...”). pp.596-599. Entra en vigor con carácter general el 4 de octubre de 1967, para España el 14 de agosto de 1978 (BOE núm. 252, de 21 de octubre de 1978; corrección de errores en BOE núm.272, de 14 de noviembre).

${ }^{7}$ Creado por la Asamblea General de la ONU por resolución 319-IV de 1949.

${ }^{8}$ LÓPEZ GARRIDO, D.: El derecho de asilo. Ed.Trotta-Ministerio de Asuntos Sociales, Madrid, 1991. p. 121
} 
Sin embargo, en las últimas décadas han surgido una gran cantidad de situaciones "atípicas" que escapan al concepto de refugiado que ofrece la Convención de Ginebra. Se trata de situaciones de refugiados de hecho, que carecen de un estatuto legal de refugiado, entre las que se encuentran figuras como los refugiados "en órbita", los refugiados de facto, los refugiados en masa y los desplazados. ${ }^{9}$

A pesar de la diferencia existente entre el asilo y el refugio, la aparición de estas nuevas situaciones "atípicas" ha llevado a una asimilación de ambas instituciones jurídicas. $^{10}$ Sin embargo, la diferencia básica estriba, como señala GORTÁZAR ROTAECHE, en que el derecho de asilo territorial es una facultad soberana de los Estados, que consiste en dar protección en su territorio a extranjeros o apátridas, cuando el Estado de su nacionalidad u origen se la deniega o no puede garantizársela. Por el contrario, el refugio es una institución jurídica internacionalmente regulada, ya que los Estados, en base al Convenio de Ginebra de 1951, han asumido una serie de obligaciones en esta materia. ${ }^{11}$

El estatuto de refugiado establecido en la Convención de 1951 y en su Protocolo de 1967 ha cristalizado en un concepto de refugiado de Derecho internacional general, ampliamente aceptado por la Comunidad internacional y por la doctrina iusinternacionalista. A continuación pasaré a analizar dicho estatuto de refugiado según el texto ginebrino de 1951 .

\section{LA CONVENCIÓN DE GINEBRA DE 1951 Y EL PROTOCOLO DE NUEVA YORK DE 1967 SOBRE EL ESTATUTO DE LOS REFUGIADOS}

El fenómeno de los refugiados, como un fenómeno de relevancia, comienza a inquietar a la Comunidad internacional al término de la Primera guerra mundial. Es en esta época, y en el seno de la Sociedad de Naciones, cuando comienzan a parecer los primeros convenios sobre refugiados. Sin ánimo exhaustivo, podemos destacar la Convención de 28 de octubre de 1933 sobre "La Condición de los Refugiados rusos, armenios y asimilables"12, fruto de los acuerdos adoptados anteriormente para los refugiados rusos y armenios. ${ }^{13}$ Dicha Convención de 1933 reconoce por primera vez la obligación de non-refoulement que, sucintamente, consiste en que el Estado donde el

\footnotetext{
${ }^{9}$ Sobre los refugiados de hecho, véase entre otros GORTÁZAR ROTAECHE, C. J.: Derecho de asilo y "no rechazo" del refugiado. Ed.Dykinson-Universidad Pontificia Comillas, Madrid, 1997. pp.148-166; LÓPEZ GARRIDO, D.: “El derecho...” op.cit. pp.121-126.

${ }^{10}$ LÓPEZ ESCUDERO, M./ MARTÍN Y PÉREZ DE NANCLARES, J. (coords.): "Derecho Comunitario..." op. cit. p.57.

${ }^{11}$ GORTÄZAR ROTAECHE, C.J.: “Derecho de asilo...” op. cit. p.148.

${ }^{12}$ Convention relative au statut international des réfugiés. Signée à Geneve, le 28 octubre 1933 (Belgique, Bulgarie, Denmark, Egypte, France, Italie, Noruége et Tchécoslovaquie). Recueil des Traités de la SDN., núm. 3663.

13 Acuerdo de 5 de julio de 1922 relativo a la expedición de certificados de identidad a los refugiados rusos, "Recueil des Traités de la SDN", no 355, vol. LXXXIX; completado por el Acuerdo provisional de 12 de mayo de 1926 y el de 30 de junio de 1928 sobre refugiados rusos y armenios, "Recueil des Traités de la SDN", n' 2004, vol. LXXXIX. Todos ellos conceden documentos de viaje a los refugiados rusos y armenios denominado "pasaporte Nansen". Cfr. MARTÍN Y PÉREZ DE NANCLARES, J.:loc. cit. ( "La inmigración y el asilo en la Unión Europea”, Ed.Colex, Madrid, 2002).
} 
demandante de asilo pretende que se le dé refugio, no devuelva al refugiado a su Estado de origen, donde su vida o libertad corren peligro.

Posteriormente, se concluyen una serie de acuerdos que van a regular la situación de refugiados de origen alemán: "Arreglo Provisional relativo a la condición de los refugiados procedentes de Alemania" (1936) ${ }^{14}$, "Convención concerniente a la Condición de los refugiados procedentes de Alemania" (1938) ${ }^{15}$ y "Protocolo Adicional al arreglo provisional y a la Convención" (1939) ${ }^{16}$.

En definitiva, se puede comprobar que se trata de instrumentos que tratan de solucionar problemas de refugiados en casos concretos. Son Convenios, Acuerdos o Arreglos "sectoriales" que no ofrecen una visión global del problema de los refugiados.

En una etapa anterior al Convenio de Ginebra de 1951 se comienzan a utilizar criterios individuales en la determinación de la condición de refugiado, ya que hasta entonces la protección se dirigía a grupos de personas: rusos, alemanes, etc.

Como consecuencia de la Segunda guerra mundial, el problema de los refugiados alcanza gran relevancia dentro de la Comunidad internacional. En principio, se considera que se trata de un problema transitorio motivado por los desastres de la Segunda guerra mundial.

Será en esta época de la segunda postguerra mundial cuando Naciones Unidas cree la Organización Internacional para los Refugiados (OIR) en $1946 .{ }^{17}$ Posteriormente dicha organización se transformará en el Alto Comisionado de Naciones Unidas para los Refugiados (ACNUR) ${ }^{18}$ mediante Resolución 319 (IV) de 3 de diciembre de 1949. Seguidamente, la Asamblea General de NU por Resolución 428 (V) de 14 de diciembre de 1950 adopta el Estatuto de Alto Comisionado de la Naciones Unidas para los Refugiados, encargado de proteger legalmente a los refugiados, sin ningún tipo de límites por su origen.

Sin embargo, no será hasta 1951 cuando se convoque la Conferencia de Plenipotenciarios ${ }^{19}$ que, reunidos en Ginebra de 2 al 25 de julio de 1951, adopten el

${ }^{14}$ Arrengement provisoire concernant le statut des réfugiés provenant d'Allemagne, avec annexe. Signée a Géneve, le 4 juillet 1936. Recueil des Traités de la SDN, núm. 3952. Cfr. GORTÁZAR ROTAECHE, C.J.: loc.cit. ("Derecho de asilo...") p. 100.

${ }_{15}$ Convention concernant le statut des réfugiés provenant d'Allemagne, avec annexe. Signée a Géneve, le 10 février 1938. Recueil des Traités de la SDN, núm. 4461. Cfr. GORTÁZAR ROTAECHE, C.J.: loc. cit.(“Derecho de asilo...”)p.100.

${ }_{16}$ Protocole additionnel à l'Arrengement provisoire et à la Convention signés respectivement à Géneve, le 4 juillet 1936 et le 10 février 1938, concernant le statut des réfugiés provenant d'Allemagne. Ouver à la signature à Géneve, le 14 septembre 1939. Recueil des Traités de la SDN, núm. 4634. Cfr. GORTÁZAR ROTAECHE, C.J.: loc.cit. (“Derecho de asilo...”) p.100.

${ }^{17}$ Sobre la historia de la OIR véase BALOGH,E. "World Peace and the Refugee Problem". Recueil de Cours. ADILH. vol. 75, 1949/II. pp. 430-465.

${ }_{18}$ Sobre su historia, estructura y actividad desarrollada, véase BEIGBEDER,Y: Le Haut Commissariat des Nations Unies por les réfugiés. Ed.Presses Universitaires de France, París, 1999.

19 En la Conferencia están representados diecisiete Estados europeos, seis americanos, cuatro asiáticos, uno de äfrica y otro de Oceanía. Concretamente, y por orden alfabético, los Estados representados son los siguientes: Australia, Austria, Bélgica, Brasil, Canadá, Colombia, Dinamarca, Egipto, Estados Unidos, Francia, Grecia, Ciudad del Vaticano, Irak, Israel, Italia, Luxemburgo, Mónaco, Noruega, Países Bajos, Reino Unido, República Federal de Alemania, Suecia, Suiza (que representa también a Liechtenstein), Turquía, Venezuela y Yugoslavia. Cuba e Irán enviaron 
Convenio de Ginebra de 28 de julio de 1951 sobre el Estatuto de los Refugiados, que entrará en vigor en 1954.

En principio, se trata de un Convenio que pretende dar solución al problema de refugiados creado por la Segunda guerra mundial. Ello cabe deducirlo por los límites (temporal y espacial) que se incluyen el concepto de refugiado.

Por su parte, el Convenio de Ginebra de 1951 establece la condición de refugiado de la que, en principio, sólo se van a poder beneficiar aquéllos que sean refugiados como consecuencia de acontecimientos ocurridos con anterioridad al primero de enero de 1951 (límite temporal). Asimismo, la Convención permite a los Estados proteger a los refugiados que provengan de cualquier parte del mundo, o hacerlo únicamente respecto de aquéllos que procedan de Europa (límite espacial). ${ }^{20}$

Así, como vemos, a pesar de que la Convención de Ginebra poseía una perspectiva más global de la problemática de los refugiados que los Convenios elaborados en la época de la Sociedad de Naciones, también estaba dirigido a solucionar la situación de los refugiados como consecuencia de la segunda gran guerra o de la guerra fría.

Ahora bien, debido a propio devenir de los acontecimientos, que demostraron que el problema de los refugiados no era una cuestión transitoria, el Protocolo Adicional al Convenio firmado en 1967 eliminó el límite temporal. ${ }^{21}$ Sin embargo, el límite espacial sólo fue eliminado en parte, ya que el Protocolo sólo contempla la supresión de dicho límite geográfico respecto de las nuevas adhesiones (Estados que no son parte de la Convención), manteniéndose para quienes ya fueran parte del Convenio y quieran adherirse al Protocolo de $1967 .^{22}$ Dicha limitación, que podría tener sentido en aquella época, debido a que el Convenio había nacido para afrontar el problema de los refugiados como consecuencia de la Segunda guerra mundial en Europa, carece hoy en día de toda justificación. $^{23}$

Como ya he señalado, la Convención de Ginebra de 1951 regula el estatuto de refugiado. Sin embargo, a pesar de lo establecido en el Art. 14 de la Declaración Universal de los Derechos del Hombre de $1948^{24}$ sobre el derecho a buscar y disfrutar

observadores. WEIS, P.(ed): The Refugee Convention, 1951. The Travaux preparatoires analysed. Cambridge, 1995. pp. 3-4.

${ }^{20}$ GORTÁZAR ROTAECHE, C.J.: “Derecho de asilo... ”op.cit.pp104-105.

${ }^{21}$ El artículo 1,2 del Protocolo señala: "A los efectos del presente Protocolo y salvo en lo que respecta a las aplicaciones del párrafo 3 de este artículo, el término refugiado se aplicará a toda persona comprendida en la definición del artículo 1 de la Convención, en la que se darán por omitidas las palabras "como resultado de acontecimientos ocurridos antes del 1 de enero de 1951 y ..." y las palabras "...a consecuencia de tales acontecimientos", que figuran en el párrafo 2 de la sección A, del artículo 1".

${ }^{22}$ El artículo 1,3 del Protocolo señala: "El presente Protocolo será aplicado por los Estados parte en el mismo, sin ninguna limitación geográfica, no obstante, serán aplicables también en virtud del presente Protocolo las declaraciones vigentes hechas por los Estados que ya sean parte en la Convención en conformidad con el inciso a) del párrafo 1 de la sección B del artículo 1 de la Convención, salvo que se hayan ampliado conforme al párrafo segundo de la sección B del artículo 1".

${ }_{23}$ A pesar de ello, Italia ha mantenido dicha limitación geográfica hasta 1990. Véase IJRL. Vol. 2, núm. 2, 1990. pp. 279-280.

${ }^{24}$ Declaración Universal de Derechos del Hombre, Nueva York, 10 de diciembre de 1948, aprobada mediante Resolución 217(III) de la Asamblea General de las Naciones Unidas; publicado por ejemplo en TORRES UGENA, N. op. cit. (“Textos normativos...”). pp.545-548. 
asilo en otros Estados si se sufre persecución, dicho derecho de asilo no es recogido en el Convenio de Ginebra de 1951.

El concepto de refugiado que recoge el Convenio de 1951 es de corte individualista, y en el mismo no se hace referencia alguna al derecho de asilo; salvo en el Acta Final de la Conferencia y en el Preámbulo del Convenio. Por ello, tal y como señala MARTÍN Y PÉREZ DE NANCLARES, del texto ginebrino no cabe, en forma alguna, derivar "un deber general de Derecho Internacional Público que obligue a los Estados a garantizar el asilo a todo extranjero que lo solicite, sino únicamente de la codificación del más modesto principio del non refoulement". ${ }^{25}$

Efectivamente, el Convenio de Ginebra no proporciona al individuo un derecho subjetivo al asilo, sino que el derecho de asilo sigue siendo una competencia soberana de cada Estado. Por contra, el Art. 33 del Convenio de 1951 sí ha "positivizado" el principio u obligación de non-refoulement, que como obligación de Derecho internacional general, impide a un Estado enviar al extranjero, a un país en el que pudiera sufrir violación de sus derechos humanos fundamentales. ${ }^{26}$ Pero sobre la obligación de non-refoulement -como obligación de Derecho internacional general, y más concretamente como obligación recogida en el Convenio de 1951- hablaré en el siguiente apartado.

Por último, cabe señalar que la Asamblea General de NU aprobó mediante Resolución 2312 (XXII) de 14 de diciembre de 1967 una Declaración sobre Asilo Territorial en la que también se contemplaba la obligación de non-refoulement. Sin embargo, la Conferencia de NU que trató de convertir dicha Declaración en un tratado internacional sobre el asilo territorial en 1977 fracasó $^{27}$; por lo que -como ya he señalado- no hay ningún texto internacional que regule el asilo territorial.

\section{LA ADMISIÓN DE REFUGIADO: LA OBLIGACIÓN DE NON- REFOULEMENT. ESPECIAL REFERENCIA AL ART. 33 DE LA CONVENCIÓN DE GINEBRA DE 1951.}

He considerado oportuno tratar la obligación de non-refoulement en un apartado distinto y anterior al que dedicaré al concepto de refugiado según el Convenio de Ginebra de 1951, debido a que como trataré de explicar, es una obligación para los Estados que "beneficia" no sólo al refugiado definido legalmente conforme al Convenio de 1951 sino que "beneficia" a todo refugiado de hecho. Es más, la obligación de non-refoulement no juega sólo respecto a quienes hayan obtenido ya el estatuto de refugiado conforme a la Convención de 1951, sino que lo hace respecto a todo solicitante de asilo. En consecuencia, cabe señalar que se trata de un principio de Derecho internacional general que juega más allá del "estrecho" límite de la Convención de $1951{ }^{28}$

\footnotetext{
${ }^{25}$ MARTÍN Y PÉREZ DE NANCLARES, J.: La inmigración y el asilo en la Unión Europea. Ed.Colex, Madrid, 2002.p.19.

${ }^{26}$ GORTÁZAR ROTAECHE, C.J.: “Derecho de asilo y...”op.cit.p.287.

${ }^{27}$ MARTÍN Y PÉREZ DE NANCLARES, J.: “La inmigración y el asilo...”op.cit.p.19.

${ }^{28}$ GORTÁZAR ROTAECHE, C.J.: “Derecho de asilo...”op.cit.pp.287-368.
} 
En primer lugar, trataré la obligación de non-refoulement conforme al Convenio de 1951 y la problemática que conlleva; para después señalar su extensión a un concepto más amplio, solicitantes de asilo y refugiados de hecho.

La regulación convencional de la obligación de non-refoulement se encuentra en el Art. 33 de la Convención de Ginebra de 1951:

1.- Ningún Estado Contratante podrá, por expulsión o devolución, poner en modo alguno a un refugiado en las fronteras del territorio donde su vida o su libertad peligre por causa de raza, religión, nacionalidad, pertenencia a determinado grupo social o de sus opiniones políticas.

2.- Sin embargo, no podrá invocar los beneficios de la presente disposición el refugiado que sea considerado, por razones fundadas, como un peligro para la seguridad del país donde se encuentra o que, habiendo sido objeto de una condena definitiva por delito particularmente grave, constituya una amenaza para la Comunidad de tal país.

De esta forma, la obligación de non-refoulement contenida en la Convención de 1951 prohibe a un Estado expulsar o devolver forzosamente a un refugiado a cualquier país en el que su vida o su libertad se encuentren amenazados por motivos de raza, religión, nacionalidad, pertenencia a determinado grupo social o por opiniones políticas.

El ámbito personal de aplicación de la obligación de non-refoulement se circunscribe al concepto de refugiado recogido en el Art. 1 de la Convención de 1951. ${ }^{29}$ Dicho concepto de refugiado es aplicable de forma individual, por lo que la obligación de nonrefoulement se aplicará individualmente, y únicamente, a aquél que tuviera el estatuto legal de refugiado conforme al Convenio de 1951. Sin embargo, la práctica de los Estados señala que la obligación de non-refoulement es aplicable también a los solicitantes de asilo, a los refugiados de hecho y a los refugiados en masa que no gocen de la protección del Estado de su país de origen.

En este sentido, la obligación de non-refoulement no se ha visto únicamente ampliada en su ámbito de aplicación personal, sino que su ámbito de aplicación material también se ha ampliado a otros campos, como los procedimientos de extradición de un refugiado a un Estado en el que haya razones para pensar que pueda ser perseguido. ${ }^{30}$

En definitiva, la obligación de non-refoulement ha sobrepasado los límites de la Convención de Ginebra de 1951, y se ha configurado como un principio de Derecho internacional general. Así, tal y como señala GORTÁZAR ROTAECHE, "la obligación de non-refoulemet, ..., comprende también la prohibición de enviar al extranjero a un país

\footnotetext{
${ }^{29}$ Dicho artículo 1.A señala: "A los efectos de la presente Convención, el término "refugiado" se aplicará a toda persona:..." y añade en su apartado $2^{\circ}$ : "Que..., debido a fundados temores de ser perseguido por motivos de raza, religión, nacionalida, pertenecia a determinado grupo social u opniones políticas, se encuentra fuera del país de su nacionalidad y no puede o, a causa de dichos temores, no quiere acogerse a la protección de tal país; o que, careciendo de nacionalidad y hallándose, a consecuencia de tales acontecimientos, fuera del país donde antes tuviera su residencia habitual, no pueda o, a causa de dichos temore, no quiera regresar a él".

${ }^{30}$ LÓPEZ GARRIDO, D.: “El derecho de asilo”op.cit.p.49.
} 
en el que por cualquiera razones pudiera sufrir tortura, tratos inhumanos o degradantes $\mathrm{u}$ otras graves transgresiones de sus derechos humanos fundamentales". 31

Asimismo, la obligación de non-refoulement se extiende respecto de las entradas ilegales de los solicitantes de asilo. Éstos no serán sancionados penalmente por su entrada o presencia ilegales, siempre y cuando se presenten inmediatamente a las autoridades y aleguen causa justificada de su entrada o presencia ilegales, tal y como establece el Art. 31 del Convenio de Ginebra. ${ }^{32}$

Sin embargo, la obligación de non-refoulement no es de carácter absoluto. Dicha obligación tiene su límite en conceptos tales como "seguridad nacional" u "orden público", tal y como prevé el apartado segundo del Art. 33 de la Convención de Ginebra.

Por último, antes de pasar a analizar el concepto de refugiado conforme al Convenio de 1951, haré referencia brevemente a dos problemas que afectan a la aplicación práctica de la obligación de non-refoulement.

El primero de ellos hace referencia a si la obligación de non-refoulement se limita a aquellos refugiados que se hallen dentro del territorio donde pretenden ser "acogidos"; o por el contrario, se extiende también a las solicitudes de asilo que se encuentran en la frontera. La materia ha sido objeto de un arduo debate doctrinal, pero tal y como señala GORTÁZAR ROTAECHE, si nos atenemos al sentido que se da a la obligación de nonrefoulement en el Art. 33 -que habla de "no poner en modo alguno a un refugiado en las fronteras de territorios donde su vida o libertad peligre (...)"- cabe afirmar la inclusión del "no rechazo en frontera" dentro del concepto de la obligación de non-refoulement. ${ }^{33}$

Por último, brevemente señalaré el problema de las demandas de asilo manifiestamente mal fundadas y su incidencia en la obligación de non-refoulement. La práctica estatal ha llevado, que ante lo que las autoridades estatales consideran demandas de asilo manifiestamente mal fundadas, se deniegue incluso su admisión a trámite, vaciando de contenido la obligación de non-refoulement, ya que tales demandantes de asilo serán expulsados. En este sentido, LÓPEZ GARRIDO señala que conforme al "Manual de procedimientos y criterios a aplicar para determinar el estatuto de refugiado", el demandante de asilo debe gozar del "beneficio de la duda". ${ }^{34}$ Por ello, las autoridades estatales deben entrar en el análisis de la demanda de asilo y admitirla a trámite, para determinar si es efectivamente una demanda mal fundada. Con ello, la obligación de non-refoulement no quedaría desvirtuada. ${ }^{35}$

${ }^{31}$ GORTÁZAR ROTAECHE, C.J.: “Dercho de asilo...”op.cit. p.287.

${ }^{32}$ El mencionado Art. 31.1 señala: "Los Estados contratantes, no impondrán sanciones penales, por causa de su entrada o presencia ilegales, a los refugiados que, llegando directamente al territorio donde su vida o su libertad estuviera amenazada en el sentido previsto por el artículo 1, hayan entrado o se encuentren en el territorio de tales Estados sin autorización, a condición de que se presenten sin demora a las autoridades y alegen causa justificada de su entrada o presencia ilegales".

33 En este sentido se han pronunciado GORTÁZAR ROTAECHE, C.J.: "Derecho de asilo y...”op.cit. pp.295-313; WEIS, P.(ed): “The Refugee...”op.cit. p.341.

${ }^{34}$ ACNUR: Manual de procedimiento y criterios para determinar la condición de refugiado en virtud de la Convención de 1951 y el Prtocolo de 1967, sobre el Estatuto de los Refugiados, Ginebra, 1988.

${ }^{35}$ LÓPEZ GARRIDO, D.: “El derecho de asilo” op.cit. pp. 55-57. 


\section{EL CONCEPTO DE REFUGIADO SEGÚN LA CONVENCIÓN DE GINEBRA DE 1951 Y SU PROTOCOLO DE 1967: EL REFUGIADO ESTATUTARIO}

5.1. El concepto de refugiado. las cláusulas de inclusión

El concepto de refugiado viene recogido en el Art. 1 de la Convención de Ginebra. Su apartado A. $2^{36}$ señala que:

"A los efectos de la presente Convención, el término "refugiado" se aplicará a toda persona que debido a fundados temores de ser perseguida por motivos de raza, religión, nacionalidad, pertenencia a determinado grupo social u opiniones políticas, se encuentre fuera del país de su nacionalidad y no pueda o, a causa de dichos temores, no quiera acogerse a la protección de tal país; o que careciendo de nacionalidad y hallándose fuera del país donde antes tuviera su residencia habitual, no pueda o, a causa de dichos temores, no quiera regresar a él".

A continuación, realizaré un análisis de los elementos que integran el concepto de refugiado conforme al Art. 1.A.2) de la Convención de 1951

a. El término refugiado se aplicará a toda persona.

La primera parte de la definición del concepto de refugiado hace referencia, tal y como señala MARTÍN ARRIBAS, al derecho a solicitar el estatuto de refugiado que es una facultad que concierne a la persona física, no jurídica, y que puede o no llegar a utilizar. ${ }^{37}$ La principal conclusión que se deriva de este concepto es que la aplicación del término refugiado se hará individualmente, caso por caso, considerando a cada persona individualmente. Por tanto, el término refugiado conforme al Convenio de 1951 no se va a aplicar a grupos de personas, como pueden ser los refugiados en masa o los desplazados.

Del mismo modo, esta definición de refugiado contiene una dimensión jurídica, por lo que van a quedar excluidos de la misma aquellas situaciones de los denominados refugiados de facto, que carecen de un estatuto legal de refugiado.

En definitiva, la solicitud de concesión del estatuto de refugiado va a ser analizada individualmente, teniendo en cuenta el caso concreto del que se trate.

\footnotetext{
${ }^{36}$ Habiendo tenido en cuenta el Art. 1 del Protocolo de 1967 que señala que "se darán por omitidas las palabras "como resultado de acontecimientos ocurridos antes del 1 de enero de 1951..." y las palabras "...a consecuencia de tales acontecimientos", que figuran en el párrafo 2 de la sección A del artículo 1".

${ }^{37}$ MARTÍN ARRIBAS, J.J.: Los Estados europeos frente al desafio de los refugiados y el derecho de asilo. Ed.Dykinson-Universidad de Burgos, Madrid, 2000. p.55.
} 
b. Que debido a fundados temores de ser perseguida.

La cuestión fundamental en este punto es que para que una persona pueda obtener el estatuto legal de refugiado debe tener fundados temores de ser perseguido en el país del que huye.

Se trata de una cuestión ampliamente estudiada por la doctrina. ${ }^{38}$ El elemento clave reside en la distinción entre un factor subjetivo y otro objetivo.

Por una parte la noción de "temor" es evidentemente subjetiva. Una persona determinada puede sufrir temor a ser perseguido en unas concretas circunstancias; mientras que otra, ante las mismas circunstancias puede perfectamente carecer de dicho temor. En este sentido el "Manual de procedimiento y criterios para determinar la condición de refugiado" (en adelante, "Manual") hace referencia a un análisis tanto de las reacciones psicológicas del individuo como de la verosimilitud de las declaraciones hechas.

El elemento del "temor" -claramente subjetivo- está complementado con el término "fundados". Ello conlleva, que en la determinación de la condición de refugiado no va a jugar únicamente un estado de ánimo, sino que requiere que dicho temor esté fundado en una situación objetiva. En este sentido, las autoridades del Estado "de acogida" valorarán la situación del país de origen del demandante de asilo. Tal y como señala el "Manual", el temor debe ser considerado como fundado, si el demandante puede demostrar que "la vida se ha convertido en intolerable para él en su país de origen por las razones indicadas en la definición, o que lo sería, por las mismas razones, si regresara". ${ }^{39}$

En este sentido, por lo que respecta al ámbito español, es preciso señalar que el Art. 8 de la Ley de asilo española ${ }^{40}$ ha propiciado la doctrina de los "indicios suficientes". Esta doctrina, elaborada por el Tribunal Supremo ${ }^{41}$, habla de la necesidad de que el demandante de asilo aporte indicios suficientemente acreditativos de que concurren en él causas objetivas de sufrir, o poder sufrir, persecución. Esta postura fue suavizada por el Tribunal Supremo en $1988^{42}$, ya que el Tribunal Supremo señaló que no es posible una prueba plena respecto al elemento objetivo, haciendo hincapié en la valoración del elemento subjetivo.

${ }^{38}$ Véase JAEGER, G. Status and International Protection of Refugees, Interrnational Institute of Human Rights, 9th Study Session (1978); WEIS, P.: The concept of Refugee in International Law. Un Doc HCR/INF/49, Journal du Droit International (1960).

${ }^{39}$ ACNUR: “Manual de procedimiento...”op.cit. pp.12-13.

${ }^{40}$ Ley 5/1984, de 26 de marzo, reguladora del derecho de asilo y la condición de refugiado; modificada por Ley 9/1994, de 19 de mayo. BOE de 27 de marzo de 1984 y BOE de 23 de mayo de 1994. El Art. 8 señala: "Para que se resuelva favorablemente una petición de asilo bastará que aparezcan indicios suficientes, (...), para deducir que se dan algunos de los supuestos de la ley”.

${ }^{41}$ El Tribunal Supremo ha recogido en diversas ocasiones la necesidad de que el demandante de asilo aporte pruebas que conlleven "indicio suficientemente acreditativo" de la concurrencia en aquél de alguno de los supuesto del art. $3^{\circ}$ (de la Ley de Asilo 5/1984). T.S. 9 de mayo de 1985. Sala $3^{\text {a }}$ de lo Contencioso-Administrativo. RAJ núm. 2340.

${ }^{42}$ T.S., 28 de septiembre de 1988. Sala $5^{\text {a }}$ de lo Contenciso-Administrativo. RAJ núm. 6945. 
Ahora bien, tal y como señala GORTÁZAR ROTAECHE, la jurisprudencia de los diferentes Estados concede más valor al elemento objetivo, y otorgan el estatuto de refugiado en base a lo bien fundado que esté el "temor de persecución". 43

Otra de las cuestiones controvertidas dentro de la doctrina y la jurisprudencia es el propio concepto de persecución. Como punto de partida cabe señalar que la Convención de Ginebra no exige haber sufrido persecución anteriormente, sino sólo tener miedo fundamentado a sufrirla en caso de regresar al país de origen. Pero, del hecho de haber sufrido persecución, si no se teme sufrirla en un futuro, tampoco se deduce ipso facto que se le reconozca el estatuto de refugiado.

La propia definición no define qué se debe entender por "persecución". Existe la duda de si por "persecución" debe entenderse "la amenaza por la vida o la libertad" que señala el Art. 33 sobre la obligación de non-refoulement. En este sentido, todo refugiado va a poderse beneficiar del non-refoulement y viceversa. $\mathrm{O}$, por el contrario, sólo se va a entender por "persecución" ciertas amenazas a la vida o a la libertad. Con ello, se podrá dar el caso de que existan personas protegidas por non-refoulement, que sin embargo no sean consideradas como refugiadas conforme al Art. 1 de la Convención de Ginebra. ${ }^{44}$

En cuanto a la persecución, haré referencia brevemente a tres aspectos relevantes de la misma. La primera cuestión hace referencia a la práctica estatal que, en ocasiones, ha interpretado el concepto de persecución exigiendo que tal persecución sea individualizada. Sin embargo, tal y como señala GORTÁZAR ROTAECHE, tal interpretación es errónea, ya que "es indiferente que lo sea individualmente o por grupo". 45

Una segunda cuestión es lo que se conoce como la alternativa de la "huida interna". Con este concepto se ha entendido que quien tiene "temores fundados de persecución" en una parte de su territorio, debe buscar en primer lugar protección en otra parte de su Estado en la cual no tema dicha persecución.

La jurisprudencia ha utilizado esta posición para denegar la condición de refugiado; sin embargo, la postura de la doctrina es contraria a esta posibilidad por las dificultades que encierra. ${ }^{46}$

Por último, cabe señalar que no es necesario que sea el Estado quien persiga al refugiado, sino que es suficiente con que el Estado no proteja, no quiera o no pueda proteger, a aquél de ser perseguido por otros grupos diferentes del Estado.

c. Las razones de los temores fundados de persecución: por motivos de raza, religión, nacionalidad, pertenencia a determinado grupo social u opiniones políticas.

\footnotetext{
${ }^{43}$ GORTÁZAR ROTAECHE, C.J.: “Derecho de asilo y...”op.cit. p.120.

${ }^{44}$ GORTÁZAR ROTAECHE, C.J.: “Derecho de asilo...” op.cit. p.112.

${ }^{45}$ GORTÁZAR ROTAECHE, C.J.: “Derecho de asilo...” "op.cit. p.114.

46 GOWLlAND-DEBBAS, V.: The Problem of Refugees in the Light of Contemporary International Law. Martinus Nijhoff, La Haya, 1996. p. 103.
} 
En primer lugar, cabe señalar que cualquiera de las razones que señala el Art. 1.A.2) del Convenio de Ginebra por las que un refugiado tenga temores fundados de sufrir persecución constituyen violación de los derechos humanos y las libertades fundamentales conforme se protegen según el Derecho internacional. ${ }^{47}$ Estas razones son el fundamento o los indicios suficientes sobre los que el demandante de asilo basa, de una forma fundada, su temor a ser perseguido. Las autoridades estatales concederán el estatuto de refugiado a la vista de estas razones. A continuación, pasaré a analizar sucintamente cada una de estas razones.

En cuanto a la raza, ésta debe ser entendida en un sentido amplio. Así, lo ha puesto de manifiesto el Consejo de la Unión Europea ${ }^{48}$, quien propone incluir en el concepto de raza la pertenencia a los diferentes grupos étnicos.

En este sentido, es oportuno tener en cuenta la regulación del Art. 1 del Convenio para la Eliminación de todas las Formas de Discriminación Racial de 1965, que incluye dentro de la "discriminación racial", las discriminaciones basadas en "raza, color, descendencia, u origen nacional o étnico". 49

En cuanto a la religión, la misma posición común 96/196/JAI, de 4 de marzo de 1996, del Consejo ${ }^{50}$, establece un concepto amplio de religión, dando cabida tanto a las creencias teístas, no teístas o ateas. Sin embargo, no es suficiente pertenecer a una comunidad religiosa, sino que deben producirse discriminaciones graves basadas en las convicciones religiosas del individuo. Por lo demás, se debe tener en cuenta el Art. 18 de la Declaración Universal de Derechos del Hombre de 1948 y el Art. 18 del Pacto del Derechos Civiles y Políticos de $1966 .^{51}$

Por lo que respecta a la nacionalidad, conforme al "Manual" del ACNUR y la posición común del Consejo de 1996, debemos entender la nacionalidad no sólo como "ciudadanía" o "nacionalidad jurídica", sino como la pertenencia dentro de un mismo Estado de un grupo diferenciado por su identidad cultural o lingüística o por sus relaciones con la población de otro Estado. En este concepto amplio de nacionalidad también deben ser incluidos aquéllos que carecen de nacionalidad, los apátridas.

La pertenencia a un determinado grupo social se entiende como la pertenencia a "un grupo que tiene un mismo origen y el mismo modo de vida o el mismo status

${ }^{47}$ MARIÑO MENÉNDEZ, F.: "El concepto de refugiado en un contexto de Derecho Internacional general", REDI, nº 2, 1983, pp. 337-369, esp. p. 355.

${ }^{48}$ Posición común 96/196/JAI, de 4 de marzo de 1996, definida por el Consejo, sobre la base del artículo K.3 del Tratado de la Unión Europea relativa a la aplicación armonizada de la definición del término "refugiado" conforme al artículo 1 de la Convención de Ginebra de 28 de julio de 1951 sobre el estatuto de los refugiados (DOCE L 63 de 13 de marzo de 1996), punto 7. Esta posición común, sin embargo, carece de efecto jurídico vinculante.

${ }^{49}$ Convención internacional sobre la eliminación de todas las formas de discriminación racial, de 21 de diciembre de 1965. BOE n $^{\circ} 118$, de 17 de marzo de 1969.

${ }^{50}$ Posición común 96/196/JAI, de 4 de marzo de 1993, definido por el Consejo..., op. cit., punto 7.2

${ }^{51}$ Pacto Internacional de Derechos Civiles y Políticos, Nueva York, 16 de diciembre de 1966, aprobado mediante Resolución 2200(XXI) de la Asamblea General de las Naciones Unidas; ratificado por España mediante Instrumento de Ratificación de 27 de abril de 1977 (BOE núm. 103 de 30 de abril de 1977). 
social". 52 Ahora bien, no es suficiente el mero hecho de pertenecer a un grupo social, sino que deben existir indicios de la "enemistad" de las autoridades gubernamentales respecto a dicho grupo, porque la existencia del grupo suponga un obstáculo de la política gubernamental, y de que se vulneren los derechos fundamentales recogidos en los instrumentos jurídicos internacionales.

Por último, en cuanto a las opiniones políticas, éstas deben entenderse en un sentido amplio. La libertad de opinión pública viene garantizada por el ordenamiento internacional. ${ }^{53}$ Sin embargo, el hecho de que una persona mantenga opiniones contrarias a las de las autoridades gubernamentales no conlleva el reconocimiento del estatuto de refugiado. Por ello, la posición común 96/196/JAI, de 4 de marzo de 1996, definida por el Consejo ${ }^{54}$, establece una serie de requisitos cualificados que suponen indicios para demostrar la existencia de un conflicto político entre el refugiado y el Gobierno de su país de origen.

En cuanto a las opiniones políticas, haré referencia por último a lo que en la doctrina se conoce como "Republikflucht". Dicho término hace referencia al hecho de que la salida de una persona de un país -su huida- constituya un delito político, por lo que si el individuo regresara a dicho Estado sería perseguido. Pues bien, la jurisprudencia alemana incluye este supuesto como válido para otorgar la condición de refugiado conforme al Convenio de Ginebra de $1951 .{ }^{55}$

\section{d. Se encuentra fuera del país de su nacionalidad.}

El solicitante de asilo que pretenda le sea reconocida la condición de refugiado conforme al Convenio de Ginebra debe estar fuera del país de su nacionalidad. Se trata de un requisito imprescindible, puesto que en principio la protección internacional no es operativa en el territorio del Estado de origen. En este ámbito la nacionalidad tiene un sentido restrictivo, y se refiere únicamente a la nacionalidad jurídica.

El primer paso será determinar la nacionalidad del refugiado, que se hará mediante un pasaporte o cualquier otro documento identificativo. En caso de que carezca de éstos, las autoridades estatales deberán realizar las investigaciones precisas para determinar la nacionalidad del refugiado.

${ }^{52}$ LÓPEZ GARRIDO, D. : “Derecho de asilo”...op.cit. p.70. Este mismo concepto es el que se encuentra en la posición común 96/196/JAI, de 4 de marzo de 1996, definida por el Consejo,... op.cit., punto 7.5 .

${ }_{53}$ Así se recoge en el Art. 19 de la Declaración Universal de los Derechos del Hombre de 10 de diciembre de 1948, el Art. 19 del Pacto Internacional de las derechos civiles y políticos de 19 de diciembre de 1966 y el Art. 10 del Convenio para la protección de los derecho humanos y las libertades fundamentales de 4 de noviembre de 1950.

${ }^{54}$ Posición común 96/196/JAI, de 4 de marzo de 1996, definida por el Consejo,...op.cit., en su punto 7.4 establece que el solicitante debe demostrar:

“- que las autoridades conocen sus opiniones políticas o bien le atribuyen unas opiniones políticas determinadas,

- que el poder no tolera dichas opiniones,

- que tiene un temor fundado a sufrir persecucuón por sus opiniones, habida cuenta de la situación reinante en su país".

${ }^{55}$ Véase GORTÁZAR ROTAECHE, C.J.: “Derecho de asilo...” op.cit. pp. 128-129. 
En el caso de que el solicitante de asilo posea más de una nacionalidad se estará a lo dispuesto en el Art. 1.A.2) del Convenio de 1951. Dicho precepto señala que la persona debe buscar protección en cualquiera de los Estados del que es nacional, por lo que no cabría la concesión del estatuto de refugiado ni la protección internacional.

Por último, haré referencia a la situación de lo que se denomina refugiados "sur place" o "in situ”. Se trata de los supuestos en los que la condición de refugiado es "sobrevenida". Es decir, es el caso de aquellos refugiados que no abandonaron ilegalmente su país, sino que estando residiendo en el extranjero, y a causa de circunstancias sobrevenidas (golpe de Estado, guerra civil), no pueden regresar a su país, y se convierten en refugiados. Dichos refugiados estarán amparados por el Convenio de Ginebra, ya que en éste sólo se señala la necesidad de que el refugiado esté fuera de su país.

e. Y no pueda o, a causa de duchos temores, no quiera acogerse a la protección de tal país.

Lo fundamental de este requisito a la hora de la determinación del status de refugiado es que se encuentre en una situación de desprotección. Ahora bien, esta condición posee dos elementos: uno objetivo y otro subjetivo.

El elemento objetivo hace referencia al hecho de que el solicitante no pueda acogerse a la protección del Estado de origen, cuestión que escapa a la voluntad subjetiva del individuo y tiene que ver más con la realidad de los hechos.

Sin embargo, el hecho de que el solicitante no quiera acogerse a la protección del Estado de origen por tener fundados temores de ser perseguido es una cuestión subjetiva del individuo y en el que el aspecto probatorio será más problemático.

En este ámbito se pueden situar los casos de aquellos solicitantes que no quieran acogerse a la protección del país de su nacionalidad por temor a ser condenado a penas por causas de objeción de conciencia, insumisión o deserción. En principio, el temor no es suficiente para que se le conceda el estatuto de refugiado por tales causas, a no ser de que se produzca persecución en las condiciones mismas de cumplimiento de las obligaciones militares; o dichas obligaciones militares impliquen la realización de acciones contempladas en la cláusula de exclusión del Art. 1.F de la Convención de Ginebra. ${ }^{56}$

f. O que, careciendo de nacionalidad y hallándose fuera del país donde antes tuviera su residencia habitual, no pueda o, a causa de dichos temores, no quiera regresar a él.

Esta última condición de cierre del sistema contempla la situación de los apátridas ${ }^{57}$ que solicitan, frente al Estado de acogida, que se les reconozca la condición de refugiados.

${ }^{56}$ MARTÍN ARRIBAS, J.J.: “Los Estados europeos frente...”op.cit. pp.66-67. Se trata de la solución dada por la posición común 96/196/JAI, de 4 de marzo de 1996, definida por el Consejo,...op.cit., punto 10 .

${ }^{57}$ Convención sobre el estatuto de los apátridas, Nueva York, 28 de septiembre de 1954. BOE núm. 159, de 4 de julio de 1997. 
Pues bien, en este ámbito lo relevante es que el criterio de la residencia sustituye al de la nacionalidad, puesto que la solicitud de refugio la presenta porque ha perdido la protección del país donde habitualmente residía, y del que ha salido.

Para terminar el apartado referente al concepto de refugiado haré mención al principio de unidad familiar. El Convenio de Ginebra de 1951 no recoge dicho concepto. Sin embargo, la recomendación establecida en el Acta Final de la Conferencia sí que aboga por el mantenimiento de la unidad de la familia del refugiado. ${ }^{58}$

\subsection{Cláusulas de exclusión.}

Las cláusulas de exclusión del concepto de refugiado, en Derecho internacional, vienen recogidas en el Art. 1, letras D, E y F de la Convención de Ginebra de 1951. A continuación, analizaré brevemente el contenido de estos preceptos.

El Art. 1.D) contempla como causa de exclusión del concepto de refugiado conforme a la Convención de Ginebra a aquellos refugiados que se encuentran bajo la protección de organismos de Naciones Unidas distintos del ACNUR. ${ }^{59}$

El Art. 1.E) excluye de la condición de refugiado a aquellas personas a las que el Estado donde hayan fijado su residencia les reconozca los derechos y obligaciones propios de los nacionales de ese país. Ello es lógico, pues tales personas gozan de la protección del país de residencia, por lo que no necesitan de la protección internacional mediante la concesión del estatuto de refugiado.

Por último, el Art. 1.F) contempla tres situaciones en las que no cabe la concesión del estatuto de refugiado:

- aquellas personas que hayan cometido un delito contra la paz, un delito de guerra o un delito contra la humanidad según están definidos en los instrumentos internacionales;

- aquéllos que hayan cometido un grave delito común fuera del país de refugio, y antes de ser admitidos en él como refugiados;

- por último, aquellas personas que sean culpables de actos contrarios a los fines y principios de Naciones Unidas.

\section{3. cláusulas de cesación}

Las cláusulas de cesación del estatuto de refugiado se recogen en el Art.1.C) de la Convención de Ginebra.

${ }^{58}$ LÓPEZ GARRIDO, D.: “El derecho de asilo”... op.cit. p.84.

59 El caso paradigmático es el de los refugiados palestinos que se encuentran bajo el amparo del Organismo de Obras Públicas y Socorro de las Naciones Unidas para los Refugiados de Palestina en el Cercano Oriente (UNRWA). Este organismo fue creado pro la Asamblea General mediante la Resolución 302(IV), de 8 de diciembre de 1949. 
En el apartado $1^{\circ}$ de dicho precepto se contempla la primera cláusula de cesación que consiste en que el refugiado, voluntariamente, se someta a la protección del país de su nacionalidad.

El "Manual" establece tres condiciones para que se aplique esta causa de cesación: voluntad, intencionalidad y éxito en la acción. ${ }^{60}$ Es decir, el refugiado debe actuar voluntariamente, querer ponerse de nuevo bajo la protección del país de origen, y conseguir dicha protección. Un ejemplo claro sería la petición y obtención del pasaporte, salvo pruebas en contrario.

El segundo supuesto de cesación de la condición de refugiado lo constituye el hecho de que, habiendo el refugiado perdido su nacionalidad, la solicite y la recupere voluntariamente. Otra vez posee aquí gran importancia el hecho de que la actitud del refugiado sea voluntaria y lo haga con la voluntad de regresar y con la percepción de que no va a seguir siendo perseguido si regresa al Estado de origen. ${ }^{61}$

Una tercera causa de cesación de la condición de refugiado se refiere al hecho de que adquiera una nueva nacionalidad diferente de la del país de persecución, y disfrute, por tanto, de la protección del país de su nueva nacionalidad.

El apartado $4^{\circ}$ del Art. 1.C) contempla como causa de cesación del estatuto de refugiado la situación del refugiado que voluntariamente se vuelve a establecer en el país de persecución. En este sentido, lo importante es la voluntad de volverse a establecer en el país de origen, no siendo suficiente u simple viaje.

El último supuesto de cese de la condición de refugiado contemplado en la Convención de Ginebra -Art. 1.C.5)- hace referencia al hecho de que desaparezcan las circunstancias que motivaron la concesión del estatuto de refugiado. Un caso típico de cambio de circunstancias es el del país que pasa de un régimen dictatorial a un régimen democrático, en el cual se supone que la persona no será objeto de persecución.

El apartado $6^{\circ}$ del Art. 1.C) contempla este mismo supuesto, pero para el caso de los apátridas. En este caso el apátrida regresaría al país donde tenía su residencia habitual.

Ya fuera del ámbito propio de las cláusulas de cesación, el "Manual” contempla el supuesto de "revocación". Se trata del supuesto en el que una vez concedido el estatuto de refugiado a una persona, posteriormente se descubra que no reunía las condiciones necesarias para que se la hubiera reconocido tal status. Pues bien, en estos casos se revocará la condición de refugiado a esa persona. Y como nunca tuvo la condición de refugiado en sentido estricto, los efectos de dicha revocación serán ex-tunc; y no ex-nunc, como en el supuesto de las cláusulas de cesación.

\footnotetext{
${ }^{60}$ LÓPEZ GARRIDO, D.: “El derecho de asilo”...op.cit. pp.80-81.

${ }^{61}$ ACNUR: “Manual de procedimiento...” op.cit. p.32.
} 


\section{EL STATUS INDIVIDUAL}

6.1. La posición del solicitante de refugio y el procedimiento de tramitación de una solicitud de reconocimiento del status de refugiado.

La posición en la que se encuentra un solicitante de refugio hasta que le sea reconocido o denegado el estatuto de refugiado no viene regulado por el Convenio de Ginebra de 1951, ni por su Protocolo de 1967. Por ello, dicha situación "de espera" es regulada por el derecho interno de cada Estado.

En España, el marco normativo sobre esta materia está compuesto por la Ley 5/1984, de 26 de marzo, reguladora del derecho de asilo y la condición de refugiado; que se ha visto modificada por la Ley 9/1994, de 19 de mayo.

Del mismo modo, el procedimiento de tramitación de una solicitud de refugio no viene regulado en el Convenio de Ginebra de 1951; por lo que la determinación de dicho procedimiento es competencia del derecho interno de los Estados.

En este sentido, y dentro del seno de la Unión Europea, se ha adoptado un Convenio para la determinación del Estado responsable del examen de una solicitud de asilo. Se trata del Convenio de Dublín ${ }^{62}$, de 13 de junio de 1991, y que entró en vigor el 1 de enero de $1997 .{ }^{63}$

El convenio de Dublín tiene como objetivo el determinar el Estado responsable del examen de una solicitud de asilo presentada en cualquiera de los Estados miembros de la Unión Europea. Con ello, se trata de evitar el fenómeno del refugiado en órbita y del refugiado múltiple (conceptos que se explican en el siguiente punto).

\subsection{El status de refugiado.}

Una vez que el solicitante ha obtenido el reconocimiento de su condición de refugiado conforme al Convenio de Ginebra de 1951, accede a lo que se conoce como el status de refugiado. Dicho estatuto legal de refugiado conlleva una serie de derechos y obligaciones para el refugiado.

El reconocimiento por parte del Estado "de acogida" de la condición de refugiado a una persona es meramente declarativo, y no constitutivo. El Estado "de acogida" declara que una persona cumple los requisitos exigidos por la Convención de Ginebra para obtener el estatuto de refugiado. Por ello, el convenio de 1951 guarda silencio respecto a la situación de aquel refugiado que obtuvo el estatuto legal de refugiado en un Estado, y posteriormente establece su residencia en otro Estado Parte. Se entiende que este último Estado no tiene obligación de mantenerle la condición de refugiado, pues puede seguir criterios más estrictos en la determinación de la condición legal de refugiado. En este

\footnotetext{
${ }^{62}$ Convenio de Dublín, de 13 de junio de 1991, relativo a la determinación del Estado responsable del examen de las solicitudes de asilo presentadas en los Estados miembros de las Comunidades Europeas. DOCE C 254 de 19.8.1997.

${ }^{63}$ Para Suecia y Austria entra en vigor el 1 de octubre de 1997; y para Finlandia, el 1 de enero de 1998.
} 
sentido, cabe señalar que la concesión del estatuto legal de refugiado por parte de un Estado no tiene efectos extraterritoriales.

La excepción a lo anteriormente señalado, es el caso de los títulos de viaje otorgados por el Estado "de acogida", que son legalmente oponibles respecto de los demás Estados Parte. En este punto, el refugiado se beneficia de un reconocimiento internacional de su estatuto.

El estatuto legal de refugiado conlleva el reconocimiento de unos derechos y la asunción de una serie de obligaciones. La Convención de Ginebra de 1951 recoge los derechos de los refugiados en los Arts. 3 a 34. Por su parte, el Art.2 del Convenio establece la obligación para los refugiados de acatar las leyes y medidas que se adopten con el objeto de mantener el orden público en el Estado "de acogida".

Por lo que respecta al distinto alcance de los derechos de los refugiados, podríamos hablar de tres estadíos diferentes. En ocasiones, los derechos de los refugiados se reconocen en las mismas condiciones que para cualquier extranjero (como por ejemplo, el Art. 13 que contempla el derecho a adquirir bienes muebles e inmuebles). En otros casos, el derecho de los refugiados alcanza al trato más favorable otorgado a los extranjeros en general (tal y como se recoge en el Art.15 respecto al derecho de asociación). Por último, existen ciertos derechos reconocidos a los refugiados en las mismas condiciones que a los nacionales (tal es el caso del Art. 4 sobre la libertad religiosa). ${ }^{64}$

A continuación trataré dos aspectos de especial relevancia respecto al status individual de refugiado: el estatuto personal de los refugiados y una serie de obligaciones del Estado en favor de los refugiados nacidos del Convenio de 1951.

a. El estatuto personal de los refugiados.

El estatuto personal del refugiado viene regulado en el Art. 12 del Convenio de 1951. ${ }^{65}$ El criterio contemplado en dicho precepto es el de la aplicación de la Ley del domicilio, o subsidiariamente, de la residencia; que serán los que regulen el estatuto personal de las personas que hayan obtenido el estatuto legal de refugiado. En este sentido, tal y como señala LÓPEZ GARRIDO, "los refugiados se asimilan a los nacionales del país de su residencia efectiva para las cuestiones que tienen que ver con su estatuto personal y sus derechos civiles". ${ }^{6}$ Se trata del domicilio equiparado al lugar de residencia efectiva del refugiado.

${ }^{64}$ GORTÁZAR ROTAECHE, C.J.:”Derecho de asilo y... ”op.cit. pp. 137-138.

${ }^{65}$ El Art. 12 del Convenio de Ginebra de 1951 señala:

"1.- El estatuto personal de cada refugiado se regirá por la ley del país de su domicilio o, a falta de domicilio, por la ley del país de su residencia.

2.- Los derechos anteriormente adquiridos por cada refugiado y dependientes del estatuto personal, especialmente los derechos inherentes al matrimonio, serán respetados por todo Estado Contratante, a reserva, en su caso, del cumplimiento de las formalidades establecidas por la legislación de dicho Estado y siempre que el derecho de que se trate sea de los que habían sido reconocidos por la legislación del respectivo Estado si el interesado no hubiera sido refuhiado"

${ }^{66}$ LÓPEZ GARRIDO, D.: “El derecho de asilo”...op.cit. p.107. 
El segundo párrafo del Art. 12 señala que los refugiados no perderán los derechos anteriormente adquiridos en su país de origen, aunque hayan roto cualquier tipo de nexo con dicho país (del que pueden seguir siendo nacionales o haber perdido dicha nacionalidad).

El mencionado párrafo segundo hace especial referencia a los "derechos inherentes al matrimonio". En este sentido, GORTÁZAR ROTAECHE, recogiendo la jurisprudencia de los Estados, señala que los cónyuges poseen el derecho a divorciarse en el país de refugio conforme a las leyes de tal país, aun cuando en su país de origen el divorcio no fuera legal o no se reconocieran las causas aducidas por los cónyuges como causas de divorcio. ${ }^{67}$

\section{b. Obligaciones del Estado en favor de los refugiados.}

Existen una serie de obligaciones de cumplimiento irrenunciable por parte del Estado en favor del refugiado que se regulan en los Arts. 28, 31, 32 y 33 de la Convención de $1951 .{ }^{68}$

El Art. 28 contempla la obligación del Estado de entregar los títulos de viaje a los refugiados. Debido a que el refugiado carece de la protección de Gobierno de su país de origen, lo normal será que no posean un pasaporte nacional. Por ello, el Estado de refugio debe proporcionarles un título de viaje. Con ello, el refugiado va a poder trasladarse fuera del territorio del Estado de refugio, ya que -como he señalado- dichos títulos son legalmente oponibles respecto de los demás Estados contratantes.

Lo anterior se puede relacionar con el Art. 26 que contempla la libertad de circulación del refugiado dentro del territorio del Estado de refugio. Dicho precepto señala que el refugiado podrá escoger su lugar de residencia en el territorio de ese Estado y viajar libremente por él.

Asimismo, en la mayoría de los países, aquellas personas que han obtenido la condición de refugiado, van a obtener un permiso de residencia, bien permanente o bien temporal y renovable.

En este sentido, la residencia puede ser una fase previa a la obtención de la nacionalidad del país de refugio para aquellos casos en que la repatriación no sea posible. Ahora bien, la obtención de la nacionalidad del Estado de refugio es un aspecto que escapa al Convenio de Ginebra, y tiene que ver más con el derecho interno de cada Estado. Efectivamente, la obtención de la nacionalidad no es un derecho del refugiado, sino que es un favor que el Estado de refugio se reserva a conceder o no a las personas que reúnen las condiciones legalmente exigidas por el derecho interno de cada Estado.

Por lo que respecta al Art. 31, dicho precepto prohibe a los Estados Parte sancionar las entradas ilegales de los refugiados que viene directamente del país donde su vida o libertad están amenazadas por las razones que prevé el Convenio, siempre y cuando se

\footnotetext{
${ }^{67}$ GORTÁZAR ROTAECHE, C.J.: “Derecho de asilo y...”op,cit. p.140.

${ }^{68}$ GORTÁZAR ROTAECHE, C.J.: “Derecho de asilo y... ”op.cit. pp.143-148.
} 
presenten directamente ante las autoridades del Estado "de acogida". Ello, no obliga al solicitante de refugio a solicitarlo de forma inmediata una vez que ha llegado al país de acogida; sino que dicha exigencia de inmediatez sólo se refiere respecto a la prohibición de no imponer sanciones por la entrada o estancia ilegal.

Por su parte, el Art. 32 de la Convención de Ginebra garantiza a los refugiados que no serán expulsados del Estado de refugio, salvo por razones de seguridad nacional $\mathrm{u}$ orden público. En este sentido, el Art. 32 exige al refugiado que se encuentre legalmente en el territorio del Estado de refugio (que posea el estatuto legal del refugiado), para prohibir su expulsión a un país diferente del perseguidor. La expulsión al país perseguidor violaría además el Art. 33 de la Convención, que a continuación se señala.

Efectivamente, el Art. 33 contempla la obligación de non-refoulement (ya tratada en este trabajo). Dicha obligación prohibe la expulsión o devolución del refugiado al territorio de un Estado "donde su vida o libertad corre peligro por causa de su raza, religión, nacionalidad, pertenencia a determinado grupo social o por sus opiniones políticas". Se trata del concepto legal de refugiado de la Convención de Ginebra.

Por último, cabe señalar que el párrafo segundo del Art. 33 contempla una excepción a la obligación de non-refoulement. Efectivamente, la obligación de non-refoulement carecerá de aplicación para aquel refugiado que "sea considerado, por razones fundadas, como un peligro para la seguridad del país donde se encuentre, o que, habiendo sido objeto de una condena definitiva por un delito particularmente grave, constituya una amenaza para la comunidad de tal pais". ${ }^{69}$ Sin embargo, dicha excepción debe ser interpretada de forma restrictiva para no vaciar de contenido la obligación de nonrefoulement.

\section{REFUGIADOS DE HECHO Vs REFUGIADOS ESTATUTARIOS.}

Hasta ahora, he analizado el concepto de refugiado conforme a la Convención de Ginebra de 1951 y su Protocolo de 1967 (refugiado estatutario). Sin embargo, en las últimas décadas, los acontecimientos (por ejemplo, los desplazados con ocasión de la guerra en la ex-Yugoslavia) han demostrado la insuficiencia del concepto de refugiado que recoge el texto ginebrino. Así lo ha puesto de manifiesto la doctrina. ${ }^{70}$

Por ello, a continuación analizaré brevemente una serie de figuras de refugiados que escapan a la definición del concepto de refugiado conforme al Convenio de Ginebra, y que cabe englobar como refugiados de hecho (frente a los refugiados estatutarios o legales). En definitiva, se trata de situaciones que quedan fuera de la protección del Derecho internacional, y ante las cuales los Estados tienen libertad con respecto a la protección que pudieran o no otorgar (aunque en ocasiones también quepa englobar dentro de los refugiados de hecho a "verdaderos" refugiados conforme a la Convención de Ginebra que, sin embargo, no son reconocidos como tales por una incorrecta interpretación de la Convención de Ginebra por parte de los Estados).

\footnotetext{
${ }^{69}$ Art. 33.2 de la Convención de Ginebra de 1951, sobre el Estatuto de los Refugiados.

${ }^{70}$ Entre otros, véase GORTÁZAR ROTAECHE, C,J.: “Derecho de asilo...”op.cit. pp.134-136; MARTÍN ARRIBAS, J.J.: “Los Estados europeos frente...”op.cit. pp. 95-100.
} 
En primer lugar, haré referencia a los refugiados "en órbita". De forma muy esquemática, cabe señalar que se trata de aquellos solicitantes de refugio cuya solicitud es rechazada por un Estado. Conforme a la obligación de non-refoulement, como principio de Derecho internacional general, el Estado no puede poner al solicitante en las fronteras del Estado perseguidor. Asimismo, dicho Estado "de acogida" no se considera competente para examinar la solicitud de refugio, por lo que envía al solicitante al Estado por el que transitó en primer lugar, que será quien deba examinar la solicitud de refugio. Ahora bien, este Estado puede no estar de acuerdo, con lo que reenviará al solicitante de refugio al Estado anterior. Esto puede suceder con varios Estados, y si ninguno se considera competente, puede suceder que el solicitante de refugio esté viajando de uno a otro Estado sin que su solicitud sea atendida. Estamos ante una solicitud de asilo sin país de asilo; es decir, ante un refugiado "en órbita".

Dicho refugiado tiene dos soluciones: estar constantemente viajando de un país a otro; o bien, quedarse en un país sin obtener el estatuto legal de refugiado. Esto último da lugar a lo que se conoce como refugiado de facto.

La categoría de refugiado de facto constituye una situación fáctica y ajurídica. Dentro de ella, se dan diversos supuestos, como el caso anterior de los refugiados "en órbita" o bien la situación de los refugiados que son admitidos a permanecer en el territorio de un Estado únicamente por motivos humanitarios o políticos.

Por último, dentro de los refugiados de facto, han surgido una serie de situaciones que se conocen como refugiados con estatuto "B". Algunos Estados ${ }^{71}$ han decidido crear un segundo tipo de estatuto para estos refugiados, conocido como estatuto "B". Dicho estatuto " $\mathrm{B}$ " consiste en un permiso de residencia temporal y en la posibilidad de ejercer empleo, basado exclusivamente en razones humanitarias. En definitiva, se trata de un estatuto "devaluado" que permite a los Estados no otorgar el estatuto legal de refugiado, conforme al Convenio de Ginebra, de carácter mucho más beneficioso para el refugiado.

Una tercera categoría de los denominados refugiados de hecho son los refugiados en masa. El concepto de refugiado que recoge el Convenio de Ginebra es de carácter individual, caso por caso, y no contempla los flujos masivos de refugiados con ocasión de guerras civiles, e incluso, con ocasión de los desastres naturales.

Dentro de la categoría de refugiados en masa, cabe distinguir el caso de los desplazados. Los desplazados se diferencian de los refugiados en masa en el hecho de que conservan su estatuto de "nacional", y por ende, no plantean problemas jurídicos. Ahora bien, su situación es igualmente dramática, por lo que no deben ser ignorados por la Comunidad internacional.

Por último, me referiré a los refugiados económicos, que tampoco entran en la categoría de refugiados estatutarios conforme a la Convención de 1951. Se trata de aquellos refugiados que han huido de su país de origen con el objetivo de escapar de las míseras condiciones de vida de dichos países, y que pretenden ser acogidos en Estados con perspectivas económicas más favorables. En ocasiones, se produce una utilización abusiva del estatuto de refugiado motivada por estas circunstancias económicas, que

\footnotetext{
${ }^{71}$ Por ejemplo, Bélgica, Dinamarca, Holanda, Suecia o Portugal.
} 
quizá tengan mayor relación con las políticas de extranjería, pero se trata de situaciones que no deben ser ignoradas por los países industrializados.

\section{CONCLUSIONES}

El concepto de refugiado recogido en la Convención de Ginebra ha quedado ampliamente superado por las circunstancias de las últimas décadas. ${ }^{72}$ Es evidente la existencia de refugiados que no entran en la "estrecha" definición del Convenio de Ginebra, ni que tampoco pueden ser calificados como inmigrantes económicos (políticas de inmigración). Se trata de una zona gris de refugiados que huyen de guerras, de situaciones de extrema violencia o de la conculcación de los más elementales derechos humanos, pero que no pueden probar persecución o, tener fundados temores a la misma, por motivos de raza, religión, nacionalidad, pertenencia a un grupo social determinado o por sus opiniones políticas, tal y como establece la Convención de Ginebra.

Dichos refugiados de hecho se encuentran en una situación dramática, ya que no reciben la protección del estatuto de refugiado conforme al texto ginebrino. Sin embargo, la Comunidad internacional no puede ignorar su situación.

Existen autores que abogan por una ampliación del concepto de refugiado mediante la reforma de la Convención de Ginebra, que de cabida a las situaciones descritas. Sin embargo, con ello se correría el riesgo de quebrar el consenso universal de mínimos alcanzado por la Convención de Ginebra respecto a lo que se debe entender por refugiado. Por ello, tal y como señala GORTÁZAR ROTAECHE, quizás sea más adecuado una correcta interpretación de la Convención por parte de los Estados que dé cabida a la situación de los refugiados que carecen de la protección internacional conforme al estatuto legal de refugiado. ${ }^{73}$

En este mismo sentido, debemos destacar la potencialidad de la obligación de nonrefoulement como principio de Derecho internacional general, que puede ser un valioso instrumento a la hora de proteger la situación de los refugiados.

Asimismo, considero que la protección de estos refugiados de hecho puede llevarse a cabo mediante otros instrumentos de carácter regional. He ahí el Convenio Europeo para la protección de los derechos humanos y de las libertades fundamentales ${ }^{74}$, que a pesar de no contemplar el derecho de asilo, puede ser interpretado de tal forma que corrija las posibles lagunas de la Convención de Ginebra de $1951 .^{75}$

72 Véase ACNUR: La situación de los refugiados en el mundo. Cincuenta años de acción humanitaria. Ed.Icaria-Ministerio de Trabajo y Asuntos Sociales, Barcelona, 2000.

${ }^{73}$ GORTÁZAR ROTAECHE, C.J.: “Derecho de asilo y...”op.cit.pp. 134-136.

${ }^{74}$ Convenio Europeo para la protección de los derechos humanos y de las libertades fundamentales, Roma, 4 de noviembre de 1950 (BOE núm. 243, de 10 de octubre de 1979; y BOE núm 108, de 6 de mayo de 1994 tras su enmienda por el Protocolo núm. 11).

${ }^{75}$ MARTÍN Y PÉREZ DE NANCLARES, J.: “La inmigración y el asilo...”op.cit. pp. 215-217. 


\section{BIBLIOGRAFÍA}

- ACNUR: La situación de los refugiados en el mundo. Cincuenta años de acción humanitaria. Ed.Icaria-Ministerio de Trabajo y de Asuntos Sociales, Barcelona, 2000.

- BEIGBEDER, Y.: Le Haut Commissariat des Nations Unies pour les réfugiés. Ed.Presses Universitaires de France, Paris, 1999.

- BLANKER, D.: Asilo político en España. Garantías del extranjero y garantías del interés general. Ed.Civitas-Ministerio del Interior, Madrid, 1997.

- BOUTEILlET-PAQUET, D.: L'Europe et le droit d'asile’.Ed.L'Harmattan, París, 2001.

- CARRERA HERNÁNDEZ, J./ NAVARRO BATISTA, N.: El espacio de libertad, seguridad y justicia en la Unión Europea. Ed.Tecnos, Madrid, 1999 (Recopilación de textos).

- DÍEZ DE VELASCO, M.: Instituciones de Derecho Internacional Público. Ed.Tecnos, Madrid, 1994.

- GOWLAND-DEBBAS, V.: The Problem of Refugees in the Light of Contemporary International Law. Ed.Martinus Nijhoff, La Haya, 1996.

- GORTÁZAR ROTAECHE, C. J.: El derecho de asilo y "no rechazo" del refugiado. Ed.Dykison-Universidad Pontificia Comillas, Madrid, 1997.

- LÓPEZ ESCUDERO, M./ MARTÍN Y PÉREZ DE NANCLARES, J. (coords.): Derecho Comunitario Material. Ed.McGrawHill, Madrid, 2000.

- LÓPEZ GARRIDO, D.: El derecho de asilo. Ed.Trotta-Ministerio de Asuntos Sociales, Madrid, 1991.

- MARIÑO MENÉNDEZ, F.:

- "El concepto de refugiado en un contexto de Derecho Internacional General", en REDI, vol.35-n ${ }^{\circ} 2$, 1983. pp. 337-369.

- "La protección de los derechos de los extranjeros y en particular del derecho de asilo: Derecho internacional, Derecho europeo y Derecho español", en VV. AA.: Convulsión y violencia en el mundo/ Seminario de Investigación para la Paz, Centro Pignatelli (ed.) -Diputación General de Aragón (Departamento de Educación y Cultura), Zaragoza, 1995. pp.61-85.

- MANGAS MARTÍN, A./ LIÑÁN NOGUERAS, D.J.: Instituciones y Derecho de la Unión Europea. Ed.McGrawHill, Madrid, 1999.

- MARTÍN ARRIBAS, J. J.: Los Estados europeos frente al desafio de los refugiados y el derecho de asilo.Ed.Dykinson-Universidad de Burgos, Madrid, 2000.

- MARTÍN Y PÉREZ DE NANCLARES, J.: La inmigración y el asilo en la Unión Europea. Ed.Colex, Madrid, 2002. 
-PASTOR RIDRUEJO, J. A.: Curso de Derecho Internacional Público y Organizaciones Internacionales. Ed.Tecnos, Madrid, 1994.

- TORRES UGENA, N.: Textos normativos de Derecho Internacional Público. Ed.Civitas, Madrid, 2000.

- TRINIDAD GARCÍA, M. L./ ROBLES ALMÉCIJA, J. M.: Guía jurídica de extranjería, asilo y ciudadanía de la Unión. Ed.Comares, Granada, 1988. 